\title{
METACOGNITIVE READING STRATEGY ENHANCING ENGLISH READING COMPREHENSION
}

\author{
WARDAH \\ Penulis adalah Pengajar IAIN Pontianak, \\ Fakultas Tarbiyah \& Ilmu Keguruan, Jurusan Pendidikan Agama Islam
}

\begin{abstract}
Strategi metakognitif peserta didik dapat mengatur, merencanakan, dan mengevaluasi pembelajaran mereka sendiri. Strategi metakognitif yang digunakan untuk mengkoordinasikan proses pembelajaran. Strategi juga melibatkan berpikir tentang belajar, memantau pemikiran, dan mengevaluasi pemahaman dalam membaca. Dalam jurnal ini membahas tentang prosedur Strategi Metakognitif dalam Membaca untuk memahami bacaan. Strategi metakognitif meningkatkan konstruksi makna bacaan pembaca, memantau teks dan pemahaman bacaan, dan kemampuan mereka untuk mengevaluasi teks yang mereka baca. Kerangka membaca metakognitif ini harus akrab bagi pengajar yang mengintegrasikan proses sebelum membaca, pada saat membaca, dan setelah membaca pada proses ketika mengajar peserta didik strategi pemahaman yang efektif. Strategi Metakognitif dalam membaca membantu peserta didik untuk memantau pemikiran mereka saat membaca. Strategi Metakognitif membantu peserta didik untuk menjadi pembelajar mandiri. Pengajar secara teratur menggunakan strategi membaca metakognitif dengan peserta didik mereka, dan berharap mereka untuk juga menggunakannya secara independen. Pengajar didorong untuk menggunakan model strategi metakognitif, mendukung siswa karena mereka belajar bagaimana menggunakannya, dan kemudian mendukung peserta didik belajar bagaimana menggunakannya secara mandiri. Dalam makalah ini menunjukkan bahwa strategi metakognitif membantu peserta didik untuk menggunakan strategi yang tepat dalam memecahkan masalah dalam membaca. Strategi metakognitif membantu siswa untuk menghentikan ketergantungan mereka menggunakan kamus. Strategi ini membantu peserta didik untuk menemukan gagasan utama, informasi tersirat, informasi tersurat, referensi, dan makna kata-kata.
\end{abstract}

Kata kunci: strategi metakognitif, membaca, peserta didik

\section{INTRODUCTION}

Reading as an activity that involves the reader, the text, to get information through written text, and build the meaning based on the reader's prior knowledge is important to be learned and mastered by every learner. Reading is important skill for students, because the students must able to read and understand an English text.
Reading can be used by the English teacher as a media to teach other language skills such as listening, speaking, and writing and also language elements such as vocabulary, pronunciation, and grammar. According to Nunan (2003: 68), reading is a fluent process of readers combining information from a text and their own background knowledge to build meaning. Meaning does 
not rest in the reader nor does it rest in text. The reader's background knowledge integrates with the text to create the meaning. Furthermore, Nunan (2003: 68) defines reading as being composed of four elements; those are the text, the reader, fluency, and strategies. Meanwhile, Aebersold and Field (1997: 15) say that reading is what happens when people look at a text and assign meaning to the written symbols in that text. It not only deals with word interpretation, but also how reader interprets the intended meaning. In addition, reading as a process of readers combining information from a text and their own background knowledge to building meaning.

Reading is receptive skill which means it involves responding to text, rather than producing it. It involves making sense of text by understanding the language of the text (at word level, sentence level, and whole text level), and connecting the message of the text to background knowledge. Understanding the language of the text will lead reader to understand the connections between sentences (coherence and cohesion) in different text types depending on what is read and for what reason. Furthermore, reading is a mental, or cognitive, process which involves a reader in trying to follow and respond to a message from a writer who is distant in space and time. In summary, reading is a thinking process that enables reader to comprehend the meaning of a text trough connecting to background knowledge, understanding the connections between sentences (coherence and cohesion), understanding different text types, and applying the appropriate reading skill.

The quality of the individual teacher is integral to success of foreign language readers. Reading teacher need to be passionate about their work. They should view themselves as facilitators, helping each reader discover what works best. The good reading teacher actively teaches students what to do. Teachers need more than classroom and techniques to be success in reading class. Furthermore, Aebersold and Field (1997: 95) explain that becoming better readers, students need to become aware of how they are reading and what they could do to improve comprehension. They need to develop their level of metacognitive awareness. According to them, the term metacognitive comes from the field of cognitive psychology and it is increasingly used in language teaching and learning.

Meta means after or behind, and cognition means the act or process of knowing perception. Metacognition is the understanding what is behind, what supports or informs, readers' knowledge and perception. As teachers, the have to help their students use every possible strategy and ability available to them during the act of reading. In order to do that, teachers need to understand reading behavior as thoroughly as possible. Teachers observe and encourage the process of students' learning as it occurs during class time, and the teachers evaluate simultaneously the products of students' learning when students speak and respond.

In achieving the standard of competency in reading skill, teachers and students should involve the teaching and learning process. The aim of teaching reading is developing the students' reading skill so that they can read English text comprehensibly, efficiently, and effectively. From the principles and teaching reading above, it can be concluded that both teachers and students should develop reading instructional activities which accommodate the students' activities when reading independently. In other reason, the goal of reading is comprehension. Comprehension is ability to understand/generate meaning of text or to connect the message of the text to background knowledge. Comprehension is the reason for reading, and vocabulary 
plays a significant role in comprehension. To be able to comprehend a text, reader must use appropriate reading skills. According to Snow (2002: 11), he defines reading comprehension as the process of simultaneously extracting and constructing meaning through interaction and involvement with written language. It can be used the words extracting and constructing to emphasize both the importance and the insufficiency of the text as a determinant of reading comprehension. She says that there are three elements taking a part in the process; the reader who is doing the comprehension, the text is to be comprehended, and the activity in which comprehension is a part.

Furthermore,

comprehension means extracting the required information from a written text as efficiently as possible, rejecting irrelevant information and finding what we are looking for, quickly. She establishes that there are two main reasons for us to read, first one is for pleasure and the second one is for information. This is the fact that working with a text as if it was a series of independent units would only lead students to feel the need of understanding every single sentence, which is not necessary in order to fulfill the purpose of understanding the text and to be reluctant to infer meanings of sentences from what comes before or after them. So, in this paper will elaborate about metacognitive reading strategy enhancing English reading comprehension.

\section{CONTENT}

In this part of paper explains about the concept of metacognition and metacognitive reading strategy in reading comprehension.

\section{a. The Concept of Metacognition}

Metacognition is actively thinking about what you are reading, as you are reading. Or another way to look at it is that as you are reading something mechanically, your brain is actively building connections between the words and meaning of the passage or text. According to Anderson (2002:365), metacognition combines various attended thinking and reflective processes. His division has five primary components: (1) preparing and planning for learning; (2) selecting and using learning strategies; (3) monitoring strategy use; (4) orchestrating various strategies; evaluating strategy use and learning. It shows in the following figure:

\section{Figure 1. Anderson's Concept of Metacognition}

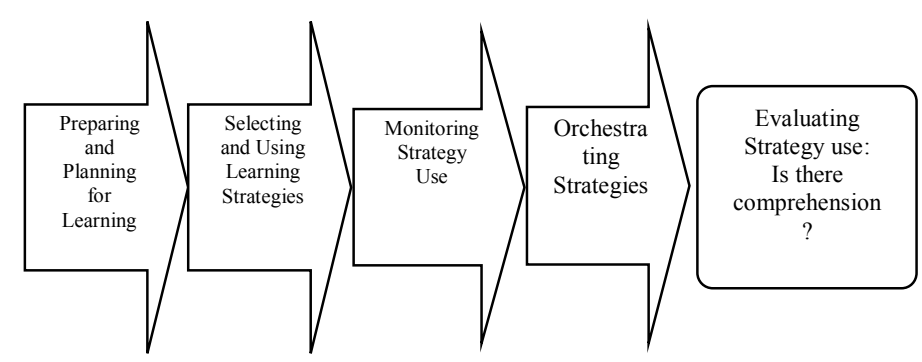

Adult learning theory emphasizes the importance of connecting new information to the existing knowledge base, so this is an important aspect in discussing metacognition in adults. Similar to Flavell, Paris and Parecki segment metacognition into self-appraisal and self-management. Self-appraisal of the cognitive process includes three types of knowledge: declarative knowledge or what affects the learning; procedural knowledge, or how the strategies operate; and conditional knowledge, which is the understanding of why and when to use strategies. Their selfmanagement is similar to Anderson's, incorporating planning, evaluation and regulation.

Metacognition plays an important role in reading comprehension. Research on metacognition has revealed that less proficient learners do not recognize the purpose of reading and tend to focus on word-byword reading rather than reading for meaning. Poor readers often finish reading passages without even knowing that 
they have not understood them. Also, poor readers are less able to adjust their reading rate to suit the purpose of reading. When they fail to comprehend the test, poor readers are not as flexible as good readers in utilizing different strategies to solve the problem. Poor readers are less efficient in monitoring their understanding of the material read or are deficient in metacognitive skills. Furthermore, by contrast, Pressley (2006:245) highlighted that good readers automatically employ metacognitive strategies to focus their attention. It concluded that since metacognitive strategies are potentially conscious and potentially controllable, learners with good metacognition are able to monitor and direct their own learning processes quite efficiently, to derive meaning, and to make adjustments when something goes wrong.

Readers who have higher metacognitive skills are able to check for confusion or inconsistency, undertake a corrective strategy, such as rereading, relating different parts of the passage to one another, look for topic sentences or summary paragraphs, and relating the current information to their past knowledge. The readers do not label these skills while performing them but if asked, they can describe their metacognitive processes accurately. They have a conscious awareness of their own knowledge and the conscious ability to understand, control, and manipulate their own cognitive processes. One of the researches was conducted by Duffy (2009:691) concerned with the findings. He looked for alternatives to the directed reading lesson that would afford greater opportunities for students to develop independent reading comprehension abilities. The result of this research identified metacognition as a way to understand reading comprehension and as an approach to comprehension instruction.

\section{b. Metacognitive Reading Strategy in Reading Comprehension}

Metacognitive is a key for success in reading. The purpose of metacognitive instruction is to help readers become more aware of their own thinking during the reading process. During instruction, teachers provide explicit instruction on the use of metacognitive reading strategies that students can employ while reading. Explicit teaching of comprehension strategies begins with a teacher clearly explaining and modeling the strategies, followed by discussion about when and how a reader should apply the strategy while reading, and finally moving to provide scaffolded student practice of the strategies during reading. Modeling strategies often occurs through teacher think- aloud methods. Through this instructional cycle, gradual transfer or release of responsibility from teacher to student is possible. Over time, students gradually become able to independently initiate and utilize that particular strategy. The cycle repeats with another strategy.

Theoretically, the strategies specific to reading can be classified in the following three clusters of metacognition: (1) planning; (2) monitoring; and (3) evaluating strategies (Israel, 2007:436). Planning strategies are used before reading; activating learners' background knowledge to get prepared for reading is an example of planning strategies. Also, previewing a title, picture, illustration, heading, or subheading can help readers grasp the overview of the text. Readers may also preview the general information in the text and its structure. Learners may check whether their reading material has a certain text structure, such as cause and effect, question and answer, and compare and contrast. Further, setting the purpose for reading can also be categorized as a planning strategy.

Monitoring strategies occur during reading. Some examples of monitoring strategies are comprehension of vocabulary, 
self-questioning (reflecting on whether they understood what they have read so far), summarizing, and inferring the main idea of each paragraph (Israel, 2007:450). Readers may also identify and focus on key information or key words, including: (1) but; (2) however; (3) on the other hand; (4) in addition; (5) also; and (6) in conclusion. Determining which part of the passage can be emphasized or ignored based on the purpose of the task is another monitoring strategy.

Evaluating strategies are employed after reading. For example, after reading a text, learners may think about how to apply what they have read to other situations. They may identify with the author, a narrative, or main character, and may have a better perspective of the situation in the book than they did at first. Besides, Metacognitive reading strategies consisted of the following: (1) setting goals for reading; (2) previewing a book before reading; (3) monitoring the appropriateness of the textbook for the purpose; (4) identifying text structure; (5) determining important information in the textbook; (6) utilizing supplemental features (such as tables); (7) using cue words and typographical support (e.g., italics); (8) inferring; and (9) confirming predictions. Metacognitive strategy is the strategies which were taught are: (1) using strengths: While reading, I exploit my personal strengths in order to better understand the text. If I am a good reader, I focus on the text; if I am good at figures and diagrams, I focus on that information; (2) inferring meaning (through word analysis or other strategies): While I am reading, I try to determine the meaning of unknown words that seem critical to the meaning of the text. (3) using background information: While I am reading, I reconsider and revise my background knowledge about the topic, based on the text's content; (4) evaluating: As I am reading, I evaluate the text to determine whether it contributes to my knowledge/understanding of the subject; (5) searching according to the goals: I search out information relevant to my reading goals;(6) reading goals: I evaluate whether what I am reading is relevant to my reading goals; (7) distinguishing: As I am reading, I distinguish between information that I already know and new information; (8) deciding on the difficulty: I note how hard or easy a text is to read; (9) revising: While I am reading, I reconsider and revise my prior questions about the topic, based on the text's content; (10) guessing the later topics: I anticipate information that will be presented later in the text.

Metacognitive strategies increase readers' meaning construction, monitoring of text and reading comprehension, and their ability to evaluate the text they are reading. This metacognitive reading framework should be familiar to teachers who integrate before, during, and after reading processes when teaching students effective comprehension strategies (Pressley, 2006:564). In summary, metacognitive reading strategies are classified into three groups of planning (pre-reading), monitoring (during reading), and evaluating (post-reading) strategies, and each group has a variety of strategies that require readers' metacognitive processing.

\section{1) Planning Strategies}

Planning strategies are metacognitive strategies that the reader does early on in the reading process (before reading) to increase reading comprehension. The following planning strategies are utilized by metacognitive readers before reading: (1) activating prior knowledge; (2) overviewing information in the text; (3) relating text to text; and (4) relating text to self.

\section{2) Monitoring Strategies}

Monitoring strategies-usually occurring during the reading of a text help the reader pay attention to meaning construction as well as correct breakdowns 
in comprehension. The following monitoring strategies are utilized by metacognitive readers during reading: (1) determining word meaning; (2) questioning; (3) reflecting, (4) monitoring; (5) summarizing; and (6) looking for important information.

\section{3) Evaluating Strategies}

Evaluation strategies used after reading that allow the reader to think critically about the text and make a cognitive or affective judgment. The following evaluating strategies are utilized by metacognitive readers after reading: (1) thinking like the author; (2) evaluating the text; (3) anticipating use of knowledge; (4) monitoring for meaning, knowing when you know, knowing when you don't know; (5) using and creating schema, making connections between the new and the known, building and activating background knowledge; (6) asking questions, generating questions before, during, and after reading that lead you deeper into the text; (7) determining importance, deciding what matters most, what is worth remembering; (8) inferring, combining background knowledge with information from the text to predict, conclude, make judgments, interpret; (9) using sensory and emotional images, creating mental images to deepen and stretch meaning; and (10) synthesizingcreating an evolution of meaning by combining understanding with knowledge from other texts/sources.

Metacognitive strategies learners can organize, plan, and evaluate their own learning. Metacognitive strategies are used to coordinate the learning process. Strategies also involve thinking about learning, monitoring one's own production, and evaluating comprehension. In this research the researcher focused on the procedure of MRS for reading comprehension. The procedure of Metacognitive Reading Strategy happened in the class to overcome the problem indicators. In the phase of Metacognitively
Oriented Reading Instruction, there is phase 1. First, the teacher introduced about Metacognitive Reading Strategy. After being first introduced to a strategy, students are not yet able to use it spontaneously. Second, the teacher repeated modeling of strategy for students through think aloud for example. One way to teach metacognition is through teacher modeling using a thinkaloud process. The teacher reads the passage and simultaneously verbalizes the thinking process occurring. The helps the students see that there are certain considerations that all readers need to make during the reading process. After modeling, students can be given a passage to read, but with the task of thinking about the strategies they are using to understand its content. A class discussion could follow where students share their own techniques and discoveries. This debriefing of the thinking process can regularly be incorporated into the activities around the reading lesson.

Beyond helping the students practice thinking about their thinking, it can assist the teacher on a diagnostic level regarding problematic areas for individual students. Teaching how to think is very different that teaching students what to think. There are a variety of techniques that can help. One is to give the students a variety of questioning techniques prior to the reading to set purpose as well as to assess comprehension afterwards. Questions like: (1) what is the main idea of this selection?; (2) how many supporting details are there?; (3) what are the supporting details; and (4) are there examples to help clarify the main idea? Before having a pre test, the teacher gave a questionnaire from the expert about cognitive and metacognitive strategy to reveal students' metacognitive awareness. After having pre test, the students review their reading strategies by answering some questions, such as: 
1. What sort of strategy that you have used to understand the reading passage?

2. How can you grasp the main idea in reading passage?

3. What do you do well as a reader in comprehending reading passage?

4. Do you have sort of specific strategy in comprehending reading?

5. What do you do before start reading?

6. What do you do while you are reading to get more idea of understanding reading?

7. What do you do when you come to a word you don't understand?

8. When you come to a part of the text that is confusing, what do you do?

9. After you finish reading, what do you do?

In the process of metacognitive reading strategy, teacher asked students to share what they recall from the lessons on background knowledge presented during the reading. There are 3 steps of MRS, such as Planning, Monitoring and Evaluating. The process of planning, monitoring and evaluating assesses by using metacognitive awareness. In planning, students implement monitoring metacognitive strategies by generating some questions to monitor their understanding while reading by asking herself some questions, such as:

1. Do I read the title and headings?

2. Do I look at the pictures?

3. Do I predict what the passage might be about?

4. Do I ask myself what I already know about the topic?

5. Do I need to read this reading passage?

6. Do I need to use organizational structure of text to help me understand this reading passage?

After planning strategy, students generate some questions in order to do evaluating and reviewing reading comprehension in monitoring strategy, such as :
1. Do I think about what I am reading?

2. Do I pause or stop sometimes and ask myself whether I understand the reading or not what I have read about so far? Do I picture in my mind the people, places, and events I am reading about?

3. Do I imagine that I am talking with the author while I am reading?

4. Do I consider some options when I am trying to answer the questions that I have asked before reading?

5. Do I need to review what I have read in order to understand the reading?

6. Do I analyze the content of reading already?

7. Do I translate the information that I have read in my own words?

8. Do I still keep myself on the track the reading?

9. Do I look for clues and try to figure it out?

10. Do I use a glossary or dictionary if I do not know the words, sentence, or passage?

In the last strategy, students generate some questions in order to do evaluating and reviewing reading comprehension, such as:

1. Do I read the text again?

2. Do I just keep reading?

3. Do I try to get help from pictures or drawings?

4. Do I think about what I have read?

5. Do I do something with the information that I have learned?

6. Do I compare what I have just read with what I already knew?

Table 1. List of Activities to use MRS to enhance students' reading comprehension

\begin{tabular}{|c|c|}
\hline Activity & Objectives \\
\hline $\begin{array}{l}\text { 1. Students } \\
\text { were asked } \\
\text { to use prior } \\
\text { knowledge } \\
\text { to think }\end{array}$ & $\begin{array}{l}\text { - To enrich their } \\
\text { knowledge about the } \\
\text { text } \\
\text { - Motivating students }\end{array}$ \\
\hline
\end{tabular}




\begin{tabular}{|c|c|c|}
\hline & $\begin{array}{l}\text { about the } \\
\text { topic }\end{array}$ & $\begin{array}{l}\text { to read the text } \\
\text { thoroughly }\end{array}$ \\
\hline & $\begin{array}{l}\text { Students } \\
\text { read silently } \\
\text { and make } \\
\text { notes about } \\
\text { mind } \\
\text { pictures that } \\
\text { emerge from } \\
\text { the words in } \\
\text { the texts }\end{array}$ & $\begin{array}{l}\text { - Helping students to } \\
\text { keep concentration } \\
\text { in reading the text } \\
\text { - Helping students to } \\
\text { visualize what they } \\
\text { read }\end{array}$ \\
\hline & $\begin{array}{l}\text { Students use } \\
\text { clues to find } \\
\text { the main } \\
\text { idea }\end{array}$ & $\begin{array}{l}\text { - Helping students to } \\
\text { find main idea easily }\end{array}$ \\
\hline & $\begin{array}{l}\text { Students } \\
\text { scan the } \\
\text { familiar } \\
\text { passage to } \\
\text { identify } \\
\text { highlighted } \\
\text { words and } \\
\text { phrases. }\end{array}$ & $\begin{array}{l}\text { - Helping students to } \\
\text { understand the } \\
\text { passage }\end{array}$ \\
\hline & $\begin{array}{l}\text { Students } \\
\text { underline } \\
\text { and make } \\
\text { highlighting }\end{array}$ & $\begin{array}{l}\text { - To note the main } \\
\text { information from the } \\
\text { text }\end{array}$ \\
\hline & $\begin{array}{l}\text { Students } \\
\text { note key } \\
\text { words from } \\
\text { the text }\end{array}$ & $\begin{array}{l}\text { To find specific } \\
\text { words for better } \\
\text { understanding in } \\
\text { reading the text }\end{array}$ \\
\hline & $\begin{array}{l}\text { Students } \\
\text { guess } \\
\text { unknown } \\
\text { words }\end{array}$ & $\begin{array}{l}\text { - To find specific } \\
\text { words }\end{array}$ \\
\hline & $\begin{array}{l}\text { Students use } \\
\text { titles to infer } \\
\text { what } \\
\text { information } \\
\text { might follow }\end{array}$ & $\begin{array}{l}\text { - To get main point } \\
\text { from the text }\end{array}$ \\
\hline & $\begin{array}{l}\text { Students } \\
\text { analyze the } \\
\text { key words in } \\
\text { the first } \\
\text { sentences of } \\
\text { the } \\
\text { paragraphs }\end{array}$ & $\begin{array}{l}\text { - To get the main } \\
\text { topic of the text }\end{array}$ \\
\hline & Students & - To understand the \\
\hline
\end{tabular}

\begin{tabular}{|c|c|}
\hline $\begin{array}{l}\text { analyze the } \\
\text { main points } \\
\text { in each } \\
\text { paragraph. }\end{array}$ & text easily \\
\hline $\begin{array}{l}\text { 11. Students } \\
\text { asking } \\
\text { themselves } \\
\text { how this } \\
\text { information } \\
\text { relates to the } \\
\text { information } \\
\text { that came } \\
\text { before }\end{array}$ & $\begin{array}{l}\text { - To get specific } \\
\text { information from the } \\
\text { text }\end{array}$ \\
\hline $\begin{array}{l}\text { 12. Students } \\
\text { look for } \\
\text { supporting } \\
\text { ideas and } \\
\text { details } \\
\end{array}$ & $\begin{array}{l}\text { - To get better } \\
\text { understanding about } \\
\text { the text }\end{array}$ \\
\hline $\begin{array}{l}\text { 13. Students } \\
\text { identify and } \\
\text { record signal } \\
\text { words } \\
\end{array}$ & $\begin{array}{l}\text { - To comprehend the } \\
\text { text organization }\end{array}$ \\
\hline $\begin{array}{l}\text { 14. Students use } \\
\text { the signal } \\
\text { words as } \\
\text { clues to find } \\
\text { the meaning } \\
\text { of the text }\end{array}$ & $\begin{array}{l}\text { - To comprehend the } \\
\text { text organization }\end{array}$ \\
\hline $\begin{array}{l}\text { 15. Students } \\
\text { identify key } \\
\text { words } \\
\text { (nouns and } \\
\text { verbs) found } \\
\text { within a } \\
\text { single } \\
\text { sentence } \\
\end{array}$ & $\begin{array}{l}\text { - To find specific } \\
\text { information from the } \\
\text { text }\end{array}$ \\
\hline $\begin{array}{l}\text { 16. Students } \\
\text { identify key } \\
\text { words } \\
\text { (nouns, } \\
\text { verbs, and } \\
\text { adjectives) in } \\
\text { a single } \\
\text { paragraph } \\
\end{array}$ & $\begin{array}{l}\text { - To find specific } \\
\text { information from the } \\
\text { text }\end{array}$ \\
\hline $\begin{array}{l}\text { 17. Students } \\
\text { recall what } \\
\text { they already } \\
\text { know about }\end{array}$ & $\begin{array}{l}\text { - To comprehend the } \\
\text { text }\end{array}$ \\
\hline
\end{tabular}




\begin{tabular}{|l|l|}
\hline $\begin{array}{l}\text { the topic or } \\
\text { concept }\end{array}$ & \\
\hline $\begin{array}{l}\text { 18. Students } \\
\text { reread for } \\
\text { getting } \\
\text { meaning }\end{array}$ & $\bullet \begin{array}{l}\text { To get better } \\
\text { understanding about } \\
\text { the text }\end{array}$ \\
\hline $\begin{array}{l}\text { 19. Students use } \\
\text { context and } \\
\text { clues for } \\
\text { hints }\end{array}$ & $\bullet \begin{array}{l}\text { To get better } \\
\text { understanding about } \\
\text { the text }\end{array}$ \\
\hline
\end{tabular}

The table above states that the example of list the activities to use metacognitive reading strategy to enhance students' reading comprehension.

\section{CONCLUSION}

In conclusion, it is important for teachers to understand the suitable method to improve the students' motivation in learning reading because it is the key of success in teaching learning process. The use of MRS has proven to be an appropriate strategy in teaching learning reading comprehension.. So teachers can use this strategy in their class. Before implementing the strategy, teachers should explain how to do the steps clearly. The teachers must guide the students patiently. Explain one by one the steps and the activities that can help students to find main idea, explicit information, implicit information, reference and meaning of words. The students should have a great motivation in learning English. They must change their mind that reading comprehension is not difficult. Students have to realize that understanding reading text needs a good and appropriate strategy. When the students apply a good and appropriate strategy, the process of understanding the reading text will be easier. The students can use MRS as a strategy that can be applied to comprehend reading comprehension.

Metacognitive strategies increase readers' meaning construction, monitoring of text and reading comprehension, and their ability to evaluate the text they are reading. This metacognitive reading framework should be familiar to teachers who integrate before-, during-, and after reading processes when teaching students effective comprehension strategies. MRS helps students to monitor their thinking while reading. MRS helps students to be independent learner. Teachers regularly use metacognitive reading strategies with their students, expecting students to also use them independently, which may or may not be the case. Teachers are encouraged to model metacognitive strategies, supporting students as they learn how to use them, and then reducing that support as students learn how to use them independently. In this research showed that MRS helps the students to use appropriate strategies in solving their reading problems. MRS helps students to stop their dependency of using dictionary. MRS helps students to find main idea, implicit information, explicit information, reference, and meaning of words.

\section{BIBLIOGRAPHY}

Aebersold, J. \& Field M. (1997). From Reader to Reading Teacher. Cambridge: Cambridge University Press.

Anderson, N. J. (2002). The role of metacognition in second language teaching and learning. ERIC

Duffy, Gerald G. (2009). Explaining Reading: A Resource Four Teaching Concepts, Skills, and Strategies. New York:The Guildford Press.

Israel, S. E. (2007). Using metacognitive assessments to create individualized reading instruction. Newark, DE: International Reading Association.

Nunan, David. (2003). Language Teaching Methodology. London: Prentice Hall International. 
Pressley, M. (2006). Reading Instruction That Works: The Case for Balanced Teaching. New York: Guilford.

Snow, Catherine. (2002). Reading for Understanding: Toward an $R \& D$ Program in Reading Comprehension. Los Angeles: RAND

Bodrova, E. \& Leong, L. J. Tools of the Mind: A Vygotskian approach to earlychildhood education. Englewood Cliffs, NJ: Merrill Publishing Company. 1996 